\title{
U-Pb dating of detrital zircons from the Sangun metamorphic rocks, Kyushu, Southwest Japan: An evidence for 1.9-2.0 Ga granite emplacement in the provenance
}

\author{
TOMOHARU MIYAMOTO and TAKERU YANAGI \\ Department of Earth and Planetary Sciences, Faculty of Science, Kyushu University, Fukuoka 812-81, Japan
}

(Received December 26, 1995; Accepted July 10, 1996)

\begin{abstract}
$\mathrm{U}-\mathrm{Pb}$ and $\mathrm{Rb}-\mathrm{Sr}$ radiometric dating has been done on zircon samples and mineral concentrates, respectively, separated from psammitic schists of the Sangun metamorphic rocks in central Kyushu, Japan. Based on their shapes and colors, zircon grains were grouped into six. Rounded and short prismatic zircons define, independently of their colors, a common discordia with an upper intercept at $1.91 \pm 0.04$ $\mathrm{Ga}$. Elongated zircons define another discordia with an upper intercept at $0.93 \pm 0.06 \mathrm{Ga}$. A Rb-Sr internal isochron defined by the mineral concentrates gives an age of $197.7 \pm 6.5 \mathrm{Ma}$, which represents the time of the Sangun metamorphism in central Kyushu.

The U-Pb age of $1.91 \mathrm{Ga}$ coincides with that of zircons from the Oki metamorphic rocks $(1.96 \pm 0.04$ Ga: Yamashita and Yanagi, 1994). This and the great abundance of $1.91 \mathrm{Ga}$ grains in the zircon populations seem to indicate a prominent plutonic activity at 1.9-2.0 Ga in the provenance common for the Sangun and Oki metamorphic rocks. The U-Pb ages of zircon from the Sangun metamorphic rocks indicate the episodic growth at 1.91 and $0.93 \mathrm{Ga}$ of the East Asian continent close to the Japanese Islands.
\end{abstract}

\section{INTRODUCTION}

The Sangun metamorphic belt is an elongated tectonic unit extending northeastward from north Kyushu through Chugoku to the central part of Honshu in Southwest Japan (Fig. 1). This belt is, however, not continuous but disrupted into large and small discrete exposures by the emplacement of Late Cretaceous to Early Tertiary granitic plutons and by the covers of later sedimentary and volcanic formations. This belt makes a pair with the Hida metamorphic belt that lies in parallel on the continental side (Miyashiro, 1961).

This pair is a Late Triassic to Early Jurassic orogenic belt formed along the eastern margin of the Asian continent. It, on the other hand, represents the major orogenic movement occurred first in the Japanese Islands. Excepting few small pieces of rocks accreted to the Japanese Islands, there is no conspicuous metamorphic nor plutonic belt older than this pair. Later successive accretion of disrupted sedimentary formations and subsequent metamorphism and plutonism occurred twice on the oceanic side of the oldest pair, resulting in the progressive growth toward the Pacific Ocean of the continental crust in these islands. Therefore, the knowledge of the provenance of sediments precursory of the Sangun and Hida metamorphic rocks is very important for understanding geologic and tectonic situations of the eastern margin of the Asian continent before the birth of the Japanese Islands.

$\mathrm{U}-\mathrm{Pb}$ dating of zircons from metamorphic rocks at the Oki Island, a western extension of the Hida metamorphic belt, indicates a marked igneous activity at their provenance at 1.9-2.0 Ga (Yamashita and Yanagi, 1994). This zircon age corresponds to the time of prominent granitic plutonism and metamorphism in the Sino-Korean shield (1.7-2.2 $\mathrm{Ga}$; Yanagi and Yamaguchi, 1970; Hurley et al., 


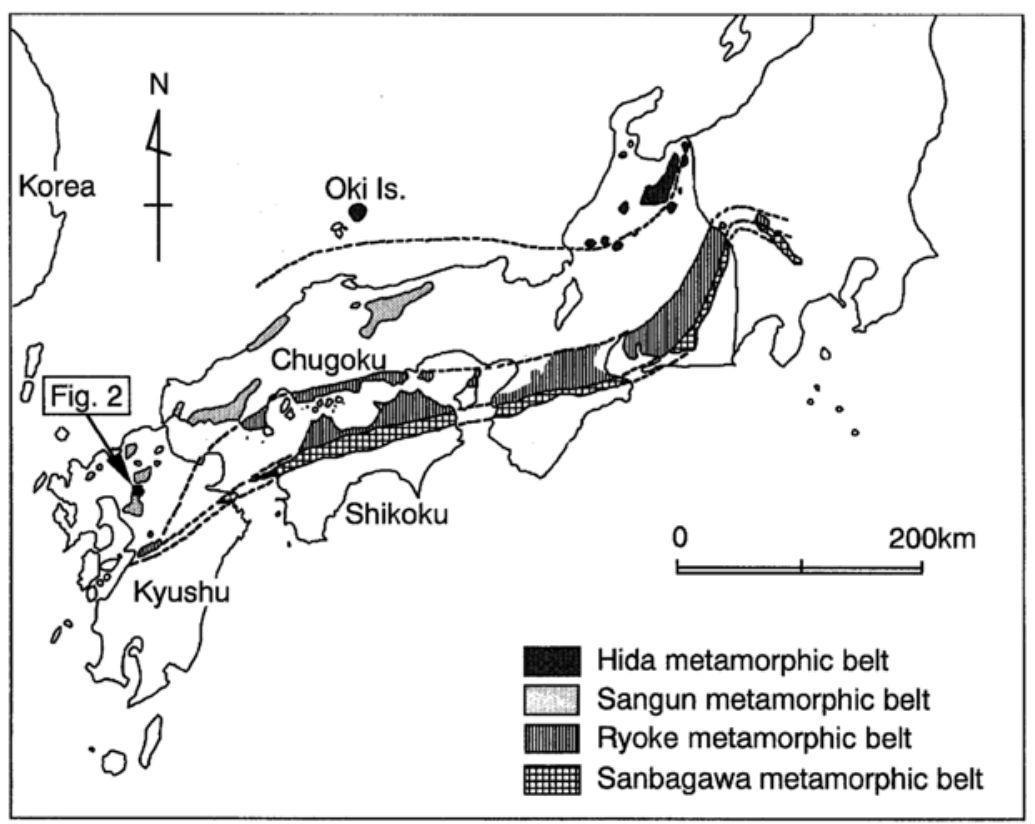

Fig. 1. Geological and structural setting of the Southwest Japan.

1973; Hamamoto et al., 1989; Sun et al., 1991).

Our major concerns about the eastern margin of the Asian continent include such problems as; 1) how extensive this igneous activity was, 2) how much and widely this igneous activity contributed through later erosion and sedimentation to the growth of the Japanese Islands, 3) whether any other younger orogenic movement occurred in the same provenance and 4) whether there is any evidence for the contributions from Archean orogenic belts to the Japanese Islands. Extensive chronological works on zircons from the Sangun and Hida metamorphic rocks and also from $\mathrm{Pa}$ leozoic sedimentary rocks are necessary along with geological survey in the continent for understanding geologic and tectonic history of the continental margin and the way how it is connected to the birth of the Japanese arcs. However, this kind of work is still very few and there is no such report from the Sangun metamorphic rocks in middle Kyushu. In this study, U-Pb dating was applied to them, along with $\mathrm{Rb}-\mathrm{Sr}$ analysis on mineral concentrates, to know an age spectrum of the granitic rocks in their provenance.

\section{Geological Setting}

The Sangun metamorphic rocks are low-grade schists formed under intermediate pressure conditions. Ultramafic rocks are associated in places in tectonic relation with nearby metamorphic rocks. $\mathrm{K}-\mathrm{Ar}$ and $\mathrm{Rb}-\mathrm{Sr}$ mineral ages so far reported show a confusingly wide spectrum that ranges from 160 to $310 \mathrm{Ma}$ with peaks at around 180,220 , and $300 \mathrm{Ma}$ (Nishimura, 1989).

Metamorphic rocks in Yame, middle Kyushu, are composed of pelitic, psammitic and basic schists. The whole succession accessible to us is about $3000 \mathrm{~m}$ thick and comprises Lower, Middle and Upper Formations (Matsumoto, 1958). The Lower Formation is composed of pelitic schists with intercalation of thin layers of basic and psammitic and quartz schists. The Middle Formation is made of a lower thick psammitic and an upper thick basic schist layer. The Upper Formation is again composed of pelitic schists with intercalation of thin basic and psammitic schist layers. They show ENE-WSW trending upright folding with a wavelength of about $14 \mathrm{~km}$ (Yanagi, 
1969). Two sets of anticlinal and synclinal axes are confirmed and run parallel with each other. An axial part of the southernmost syncline is occupied by a thick conformable intrusion of gabbro with local ultramafic masses. The intrusion is metamorphosed at the pummpellyite-chlorite grade (Yanagi, 1969).

Samples for this study were collected from big quarries of thick psammitic schists of the Middle Formation and from new road-cuts through the alternation of psammitic and pelitic schist layers of the Upper Formation (Fig. 2).

Rocks in this area are phyllites and low-grade schists derived from terrigenous sediments and basic volcanic rocks such as lava flows and pyroclastics. Basic schists, light to dark green in color, are mainly composed of chlorite, actinolite, epidote, albite, quartz and often stilpnomelane and alkali-amphibole. Pelitic schists, black in color due to carbonaceous inclusions, are made of quartz, albite, muscovite and chlorite with minor epidote and tourmaline. Garnet is often included in the pelitic schists. Garnet and biotite are major constituent minerals in higher grade schists in a narrow contact aureole around small Cretaceous granitic stocks. Psammitic schists, grey in color due to less abundant carbonaceous inclusions, are mainly composed of quartz, albite, muscovite, chlorite and often epidote. Albite sometimes grows to porphyroblastic size about a few mm across. Muscovite and chlorite are arranged parallel to form a lepidoblastic texture. Psammitic schists contain sphene, zircon, pyrite, magnetite and hematite as accessory minerals. Euhedral form of sphene crystals, yellow to orange in color, indicates their crystallization during the metamor-

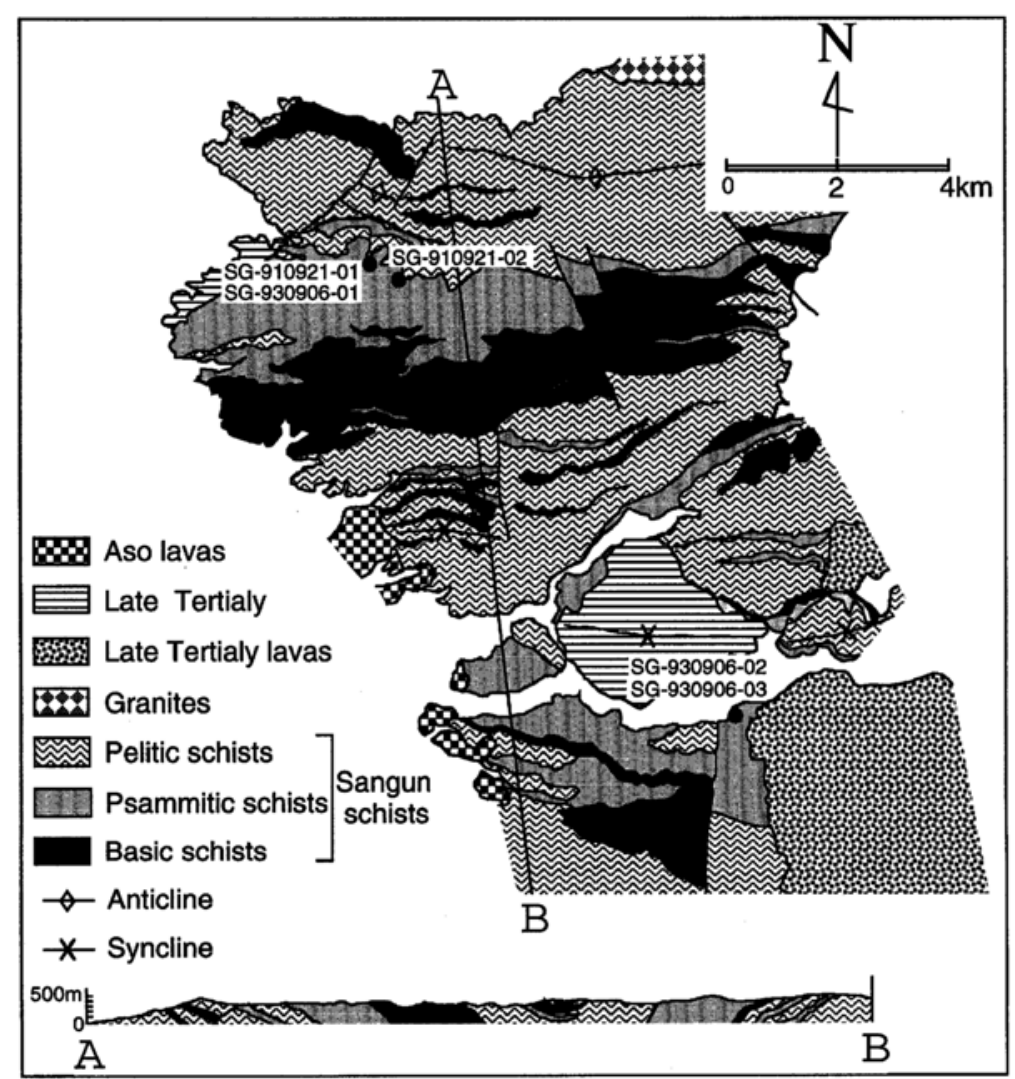

Fig. 2. Generalized geology of the Yame area, Kyushu island, Southwest Japan (modified after Inoue, 1958). 
phism. Zircon grains are all detrital, judging from crystal faces scraped during the transportation and sedimentation. Some have purple to violet color. This color, however, vanishes away in zircons in schists close to the Cretaceous granitic plutons, due to the heating during the emplacement. No overgrowth is observed on zircon grains. Sampling was done at sites sufficiently far from the contacts to avoid the effects of emplacement of the Cretaceous granitic plutons.

\section{SAMPle Preparation aND ANALYTICAL METHODS}

\section{$\mathrm{U}-\mathrm{Pb}$ analyses}

Zircon grains were separated for U-Pb dating from five psammitic schist samples of 3 to $60 \mathrm{~kg}$. After crushing, nonmagnetic fractions were separated with a Frantz isodynamic separator, and then suspended first in tetrabromoethane, subsequently in methylene iodite to collect zircon grains. Zircon grains were finally purified by hand picking under a binocular microscope.

Zircon grains so collected are all detrital with no trace of overgrowth and recrystallization. They were grouped into six fractions according to their shapes and colors (Table 1): rounded purple (RP), rounded colorless (RC), short-prismatic purple (SP), short-prismatic colorless (SC) and elongated colorless (EC). Dark translucent purple grains of rounded forms were separated into a subgroup (DP) from transparent light-purple RP grains. RC grains are all transparent. Rounded zircon grains have no original crystal edges and faces due to mechanical abrasion during the sediment transportation. SP, SC and EC grains are all euhedral with minor trace of abrasion. Short-prismatic grains (SP and SC) have aspect ratios of 1 to 3 . They mostly lack sharp crystal edges due to the abrasion, and there are many scratches on their crystal faces. SP grains are mostly transparent light-purple but a few of them are translucent dark purple. Elongated zircons (EC) show square or octagonal pillar shapes with aspect ratios greater

Table 1. Resume of samples for $\mathrm{U}-\mathrm{Pb}$ and $\mathrm{Rb}-\mathrm{Sr}$ analyses

Zircon grains for $\mathrm{U}-\mathrm{Pb}$ analysis

\begin{tabular}{ll}
\hline Rounded & $\begin{array}{c}\text { RP: Rounded purple grains } \\
\text { (DP: Rounded purple grains with dark and translucent) } \\
\text { RC: Rounded colorless grains }\end{array}$ \\
& $\begin{array}{l}\text { SP: } \text { Short prismatic purple grains } \\
\text { SC: Short prismatic colorless grains }\end{array}$ \\
$\begin{array}{l}\text { Short-prismatic } \\
\text { (aspect ratio of } 1.0 \text { to } 3.0)\end{array}$ & EC: Elongated colorless grains \\
$\begin{array}{l}\text { Elongated } \\
\text { (aspect ratio of over 4.0) }\end{array}$ &
\end{tabular}

Mineral concentrates for $\mathrm{Rb}-\mathrm{Sr}$ analysis (SG-930906-03)

AG: Total grains free from fine powder

Non-magnetic NM1: Non-magnetic grains (albite and quartz)

NM2: Non-magnetic grains $\rho<2.97$ (albite $>$ quartz)

Magnetic MG1: Magnetic grains (e.g., chlorite, muscovite)

MG2: Magnetic grains with $2.97<\rho<3.33$ (muscovite $>$ chlorite)

MG3: Magnetic grains with $3.33<\rho$ (allanite) 
than 4. They keep original crystal edges and faces with a little scratch on them. A top of their pyramids is much abraded during the transportation. EC group is simply composed of colorless transparent grains.

We employed the conventional isotope dilution method to determine lead and uranium contents in zircon samples. Reagents such as $\mathrm{HF}, \mathrm{HCl}$, $\mathrm{SiCl}_{4}$ and water were distilled with two-bottle Teflon stills (Mattinson, 1972). Nitric acid was purified five times with subboiled-type quartz stills. Dilute phosphoric acid $(0.1 \mathrm{~N})$ was purified by passing through cation exchange resin DOWEX 50W-X8, 100-200 mesh.

Sample grains were put into a Teflon microbeaker of about $10 \mathrm{ml}$, washed with hot $20 \%$ $\mathrm{HNO}_{3}$ for 30 minutes and rinsed with distilled water. Then sample grains were transferred into a Teflon micro-bomb (net volume $=1 \mathrm{ml}$ ) with one drop (ca. $0.05 \mathrm{ml})$ of $\mathrm{HNO}_{3}$ and ten drops $(0.5 \mathrm{ml})$ of $\mathrm{HF}$, and then heated to $180^{\circ} \mathrm{C}$ for a week. The sample weight for decomposition was 0.1 to $1 \mathrm{mg}$ that corresponds to tens to a hundred grains of zircon. ${ }^{235} \mathrm{U}$ spike was then added to the solution. The solution was heated again to promote complete mixing and then evaporated to dryness. The sample was resolved with $0.5 \mathrm{ml}$ of $3.1 \mathrm{~N} \mathrm{HCl}$ and heated overnight. An aliquot of the solution was spiked with ${ }^{208} \mathrm{~Pb}$ to determine the lead concentration. An aliquot was loaded on anion exchange resin DOWEX AGI $\times 8,200$ mesh to separate uranium and lead from the sample solution.

Lead isotope ratios were determined on a JEOL JMS05RB mass spectrometer with a single collector, using a silica gel technique (Cameron et al., 1969) on a single rhenium filament. No mass discrimination correction was applied. Uranium was loaded on side filaments of a triple rhenium filament alignment and analyzed on the same mass spectrometer. In the calculation of radiogenic lead, we assumed that the common lead has the present isotope composition $\left({ }^{204} \mathrm{~Pb}:{ }^{206} \mathrm{~Pb}:{ }^{207} \mathrm{~Pb}:{ }^{208} \mathrm{~Pb}=\right.$ 1:18.700:15.628:38.630; Stacey and Kramers, 1975). The lead contamination level was almost nil at 0.1 to $3 \mathrm{ng}$. Relative analytical errors are about $1 \%$ for $\mathrm{U}$ and also about $1 \%$ for $\mathrm{Pb}$. However, some lead concentrations (RP1 and RC3) have relative errors about $5 \%$.

The decay constants used are $9.8485 \times 10^{-10}$ and $1.55125 \times 10^{-10}$ year-1 for ${ }^{235} \mathrm{U}$ and ${ }^{238} \mathrm{U}$, respectively, and the present ${ }^{238} \mathrm{U} /{ }^{235} \mathrm{U}$ ratio is 137.88 (Steiger and Jäger, 1977).

\section{$\mathrm{Rb}$-Sr analyses}

Muscovite, epidote and plagioclase were concentrated from the same sample as that for $\mathrm{U}-\mathrm{Pb}$ dating (SG-930906-03; Table 1). After crushing and the elimination of fine powder with water, the grain sample was separated into two fractions: non-magnetic (NM1) and magnetic grains (MG1) with a Frantz isodynamic separator. They were such small grains that we could only concentrate by their gravity and magnetic characters. NM1 was suspended in tetrabromoethene to collect a lighter fraction (NM2). NM1 and NM2 are composed of quartz and albite grains in different proportions. NM2 is much concentrated in albite. MG1 was also suspended in the heavy liquid. The precipitated grains were then suspended in methylene iodite and separated into lighter (MG2) and heavier (MG3) fractions. MG2 consists mainly of muscovite with some chlorite grains, and MG3 consists mostly of allanite with a few muscovite grains which include fine opaque minerals. It is difficult to separate muscovite and chlorite, since their magnetic susceptibilities are overlapped with each other. These samples were analyzed along with the rock samples (RF and AG). RF is the total rock sample and AG is a crushed rock sample from which fine powder was eliminated by water.

The conventional isotope dilution method was applied to determine rubidium and strontium contents in samples (Yanagi et al., 1988). The barium coprecipitation method was employed for separation of strontium (Baadsgaard and Lerbekmo, 1980). Rubidium concentration was determined with a HITACHI RMU5G mass spectrometer, while strontium isotope composition and concentration were determined with JEOL JMS05RB mass spectrometer by measuring the isotopic composition of spiked samples (Yanagi, 
1990). Relative analytical errors of $\mathrm{Rb}$ and $\mathrm{Sr}$ concentrations are about $2 \%$ and $1 \%$, respectively. The decay constant used is $1.42 \times 10^{-11}$ year $^{-1}$ for ${ }^{87} \mathrm{Rb}$ (Steiger and Jäger, 1977).

\section{RESUlts}

$\mathrm{Rb}-\mathrm{Sr}$ analytical data on mineral concentrates and total rock of a psammitic schist sample are listed in Table 2. It should be noted that muscovite concentrate (MG2) marks the highest $\mathrm{Sr}$ content. A Rb-Sr isochron is determined by the least squares regression method (York, 1966). The iso- chron gives an age of $197.7 \pm 6.5 \mathrm{Ma}$ and an initial ratio of $0.70866 \pm 0.00009$ (Fig. 3).

$\mathrm{U}-\mathrm{Pb}$ analytical data for zircon samples are listed in Table 3 and plotted on a concordia diagram (Figs. 4 and 5 ). ${ }^{204} \mathrm{~Pb} /{ }^{206} \mathrm{~Pb}$ ratios are mostly less than 0.001 , suggesting almost insignificant levels of lead contamination. Sometimes, ${ }^{204} \mathrm{~Pb}$ ion current was too low to measure.

Rounded and short-prismatic fractions have lead-lead ages from 1.8 to $1.9 \mathrm{Ga}$, and their leaduranium data lie on or close to a common line on the concordia diagram (Fig. 4), regardless of their colors. We call these fractions the Group 1 zircons.

Table 2. Analytical data for mineral concentrates from the Sangun metamorphic rocks (SG930906-03) in Yame area, Southwest Japan

\begin{tabular}{lcccl}
\hline Sample & $\mathrm{Rb}(\mathrm{ppm})$ & $\mathrm{Sr}(\mathrm{ppm})$ & ${ }^{87} \mathrm{Rb} /{ }^{86} \mathrm{Sr}$ & ${ }^{87} \mathrm{Sr} /{ }^{86} \mathrm{Sr}^{*}$ \\
\hline AG & 69.3 & 173 & 1.158 & $0.71188 \pm 7$ \\
NM1 & 56.3 & 157 & 1.041 & $0.71150 \pm 7$ \\
NM2 & 59.1 & 163 & 1.050 & $0.71170 \pm 9$ \\
MG1 & 118 & 305 & 1.118 & $0.71185 \pm 8$ \\
MG2 & 58.4 & 366 & 0.4624 & $0.71006 \pm 10$ \\
MG3 & 28.0 & 240 & 0.3380 & $0.70956 \pm 7$ \\
RF & 99.5 & 269 & 1.071 & $0.71166 \pm 14$ \\
\hline
\end{tabular}

*Errors given are $\pm 1 \sigma$.

AG: grains free from fine powder. NM: non magnetic minerals (1: grains with all gravities, 2: with $\rho<2.97)$. MG: magnetic minerals (1: grains with all gravities, 2: with $2.97<\rho<3.33$, 3: with $3.33<\rho$ ). $R F$ : rock fragments.

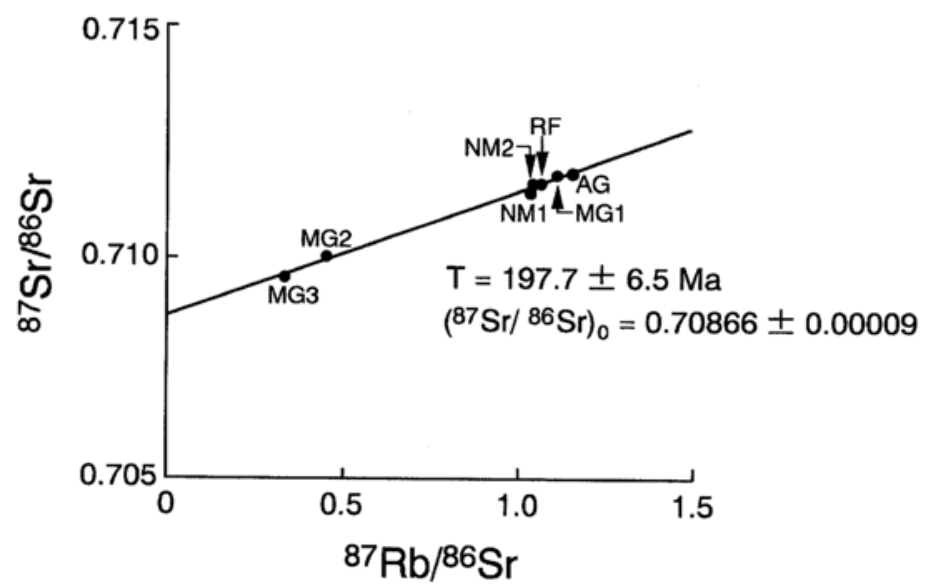

Fig. 3. Rb-Sr isochron of mineral fractions from Sangun psammitic schist sample (SG-930906-03). Errors given are $\pm 1 \sigma$. 
Table 3. Analytical data for zircons from the Sangun metamorphic rocks in Yame area, Southwest Japan

\begin{tabular}{|c|c|c|c|c|c|c|}
\hline Sample & $\mathrm{U}(\mathrm{ppm})$ & $\mathrm{Pb}(\mathrm{ppm})$ & ${ }^{204} \mathrm{~Pb} /{ }^{206} \mathrm{~Pb}^{*}$ & ${ }^{207} \mathrm{~Pb} /{ }^{206} \mathrm{~Pb}^{*}$ & ${ }^{208} \mathrm{~Pb} /{ }^{206} \mathrm{~Pb}^{*}$ & $\mathrm{~Pb}-\mathrm{Pb}$ age $(\mathrm{Ga})$ \\
\hline \multicolumn{7}{|c|}{ Rock No. 1 (SG-910921-01) } \\
\hline RP1 & 578 & 179 & $<0.00006$ & $0.1189 \pm 70$ & $0.0570 \pm 4$ & $1.94 \pm 10$ \\
\hline EC1 & 150 & 41.7 & $0.005 \pm 5$ & $0.096 \pm 20$ & $1.376 \pm 3$ & $0.93 \pm 50$ \\
\hline \multicolumn{7}{|c|}{ Rock No. 2 (SG-910921-02) } \\
\hline RP2 & 694 & 153 & $0.0015 \pm 9$ & $0.1239 \pm 32$ & $0.1168 \pm 11$ & $1.68 \pm 6$ \\
\hline \multicolumn{7}{|c|}{ Rock No. 3 (SG-930906-01) } \\
\hline DP3 & 2387 & 711 & $0.00006 \pm 2$ & $0.1180 \pm 18$ & $0.0401 \pm 1$ & $1.91 \pm 3$ \\
\hline RP3 & 544 & 163 & $0.00007 \pm 4$ & $0.1179 \pm 39$ & $0.0635 \pm 6$ & $1.91 \pm 6$ \\
\hline SP3 & 625 & 159 & $0.00023 \pm 6$ & $0.1153 \pm 22$ & $0.0556 \pm 5$ & $1.84 \pm 4$ \\
\hline $\mathrm{RC} 3$ & 195 & 28.1 & $0.001 \pm 1$ & $0.1062 \pm 76$ & $0.1892 \pm 11$ & $1.68 \pm 13$ \\
\hline SC3 & 258 & 5.67 & $0.001 \pm 1$ & $0.0644 \pm 34$ & $0.2881 \pm 4$ & $0.44 \pm 13$ \\
\hline EC3 & 418 & 23.5 & $<0.00006$ & $0.068 \pm 11$ & $0.2681 \pm 77$ & $0.88 \pm 30$ \\
\hline \multicolumn{7}{|c|}{ Rock No. 4 (SG-930906-02) } \\
\hline RP4 & 519 & 165 & $0.0004 \pm 2$ & $0.1199 \pm 2$ & $0.0646 \pm 3$ & $1.87 \pm 3$ \\
\hline SP4 & 612 & 97.5 & $0.0004 \pm 4$ & $0.1171 \pm 18$ & $0.0832 \pm 3$ & $1.90 \pm 3$ \\
\hline \multicolumn{7}{|c|}{ Rock No. 5 (SG-930906-03) } \\
\hline RP5 & 617 & 188 & $0.00020 \pm 3$ & $0.1163 \pm 39$ & $0.0589 \pm 5$ & $1.86 \pm 6$ \\
\hline SP5 & 464 & 127 & $0.0002 \pm 2$ & $0.1200 \pm 2$ & $0.0830 \pm 5$ & $1.914 \pm 3$ \\
\hline RC5 & 284 & 29.3 & $0.0004 \pm 4$ & $0.1061 \pm 8$ & $0.1979 \pm 1$ & $1.71 \pm 2$ \\
\hline SC5 & 332 & 17.0 & $0.0014 \pm 5$ & $0.0869 \pm 69$ & $0.2776 \pm 6$ & $0.84 \pm 20$ \\
\hline EC5 & 723 & 38.7 & $<0.00006$ & $0.072 \pm 11$ & $0.2844 \pm 34$ & $1.00 \pm 27$ \\
\hline
\end{tabular}

*Error given are $\pm 1 \sigma$. For error calculation, see Ludwig (1980).

$R P$ : rounded purple zircons, DP: rounded dark purple zircons, SP: short-prismatic purple zircons, RC: rounded colorless zircons, SC: short-prismatic colorless zircons, EP: elongated colorless zircons. Number indicate rock No. The terms "<0.00006" is used to indicated that intensity of ${ }^{204} \mathrm{~Pb}$ is too low for us to detect.

Elongated zircons have lead-lead ages around 0.9 $\mathrm{Ga}$ and their data lie on another line on the diagram (Fig. 5). These are called the Group 2 zircons. We used the York's least squares regression treatment (York, 1969) to fit the discordia lines to the data. Group 1 zircons, excepting RP2, define a discordia that gives an upper intercept age of $1.91 \pm 0.04 \mathrm{Ga}$ and a lower intercept age of 0.14 $\pm 0.05 \mathrm{Ga}$ (Fig. 4). Group 2 zircons define another discordia which passes through the origin of the concordia diagram (Fig. 5). Its upper intercept age gives an age of $0.93 \pm 0.06 \mathrm{Ga}$. RP2 was a mixture of rounded grains and elongated crystals, due to incomplete separation, and lies between RP and EC fractions. Accordingly, RP2 was neglected in defining the Group 1 discordia.

Purple zircons are less discordant than colorless zircon grains though they lie on the common discordia (Fig. 4). The purple zircons of both rounded and short-prismatic grains have distinctly higher uranium concentrations (460 to $2400 \mathrm{ppm}$ ) than colorless zircons (200 to $330 \mathrm{ppm}$ ).

\section{Discussion}

The Rb-Sr isochron age $(197.7 \pm 6.5 \mathrm{Ma}$ : Fig. 3) shows the time of metamorphism. Nishimura (1989) has reported $\mathrm{Rb}-\mathrm{Sr}$ mineral ages of 207 and $214 \mathrm{Ma}$ from Yame. The mineral isochron ages of this study is very close to, but a little younger than $\mathrm{Rb}-\mathrm{Sr}$ mineral ages reported by Nishimura (1989). The sample site is farther (12 $\mathrm{km})$ than those of Nishimura (1989) $(8 \mathrm{~km})$ from the nearby granitic plutons.

The lower intercept age of $0.14 \pm 0.05 \mathrm{Ga}$ is well defined but much younger than the mineral 


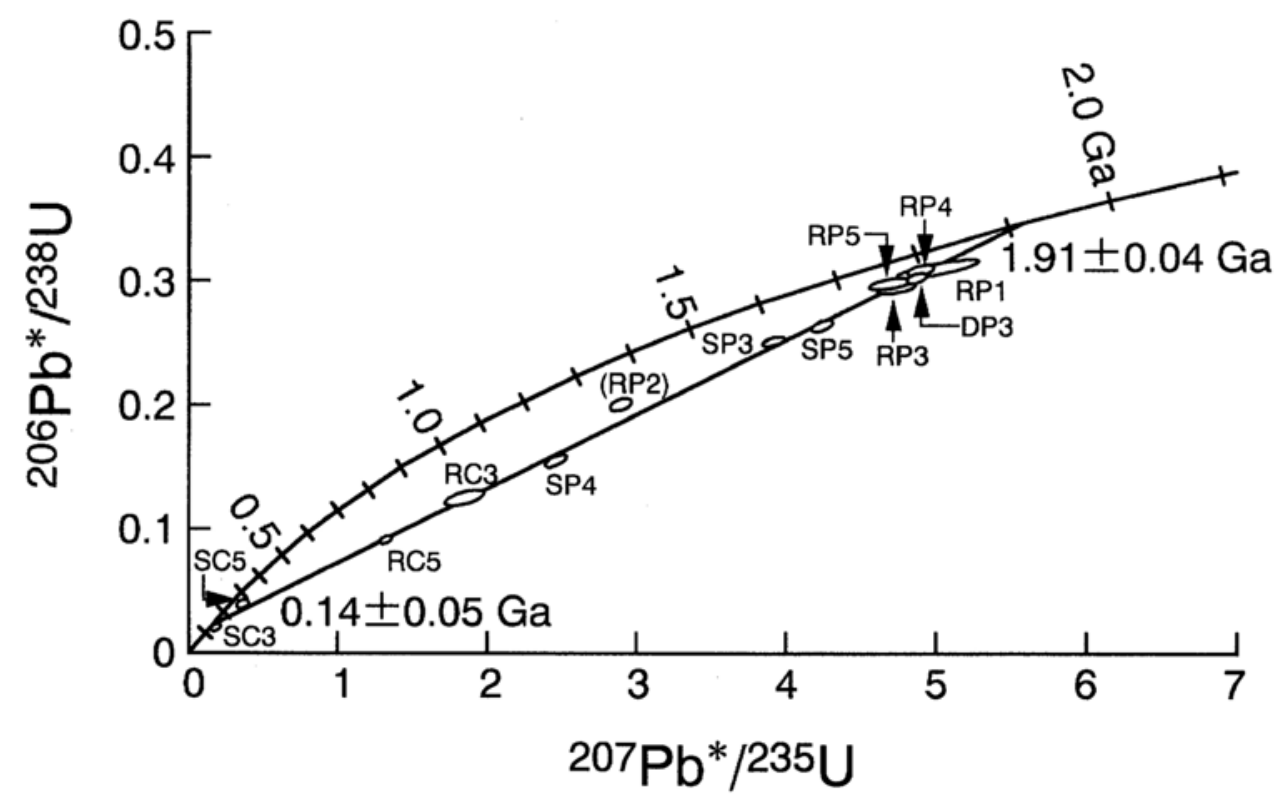

Fig. 4. Concordia diagram for data of Group 1 (rounded purple (RP, DP $=$ dark purple), short euhedral purple $(S P)$, rounded colorless (RC), and short euhedral colorless (SC) zircons) from Sangun psammitic schists.

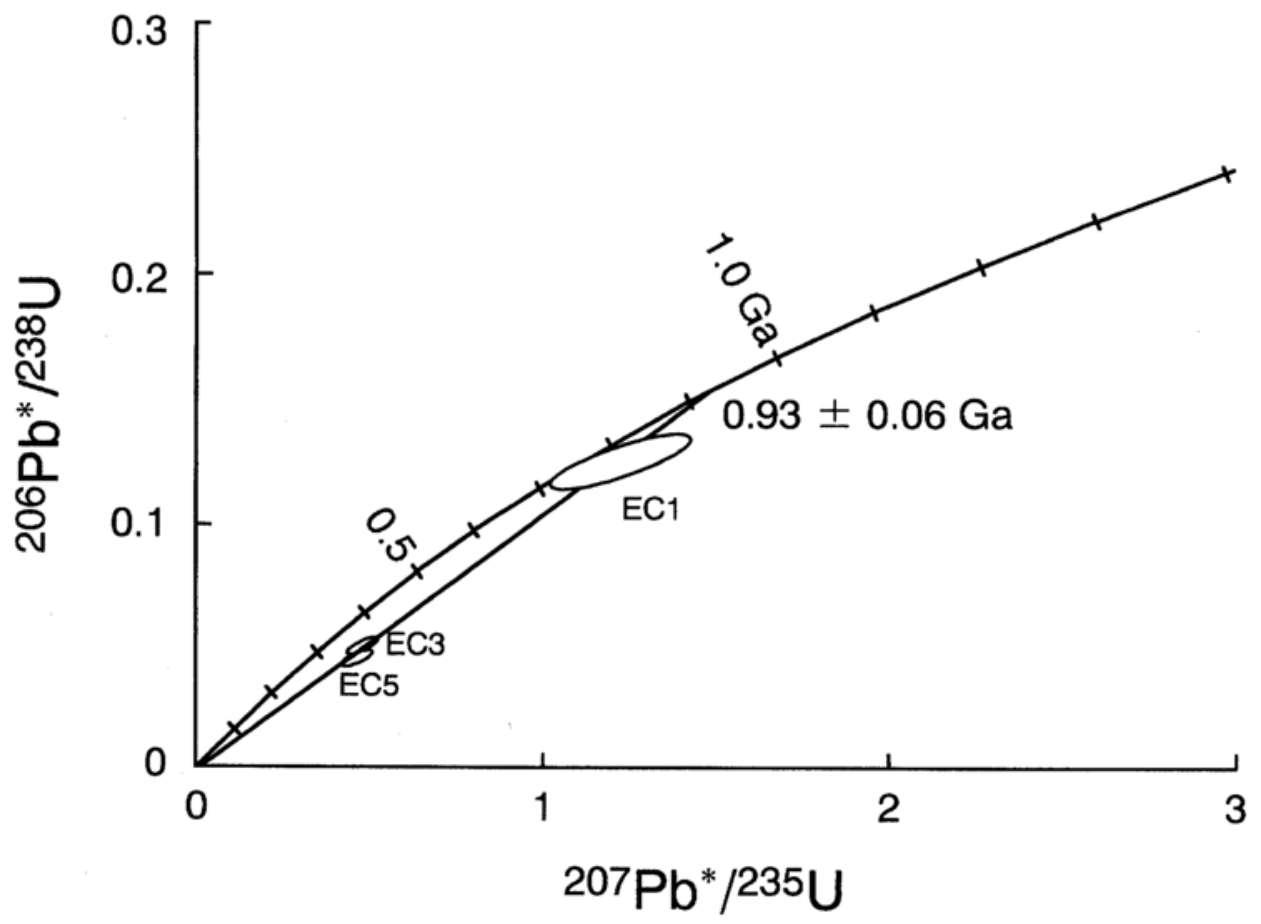

Fig. 5. Concordia diagram for data of Group 2 (elongated colorless zircons (EC)) from Sangun psammitic schists. 
isochron age of $197.7 \pm 6.5 \mathrm{Ma}$ and closer to ages of Cretaceous granitic plutons ( $c a .95 \mathrm{Ma}$ ). In connection with this observation, it should be noted that SC3 and SC5 are both lying very close to the lower intercept, indicating a loss of 98 and 93\% radiogenic lead, respectively. This suggests that these zircons were very susceptible to lead loss. Accordingly, the possibility of effect of the granitic emplacement is not rejected, although the sample sites are very far from nearby granitic plutons ( $c a .6$ and $12 \mathrm{~km}$ ). Rounded zircons lying closer to the upper intercept seem to have suffered insignificant effects of the granite emplacement, since they lost only small amounts of radiogenic lead even during the greenschist facies metamorphism.

Two upper intercept ages, 1.91 and $0.93 \mathrm{Ga}$ (Figs. 4 and 5) suggest the two major episode of granitic emplacements in the provenance. The age of $1.91 \mathrm{Ga}$ is the same as the upper intercept age $(1.96 \pm 0.04 \mathrm{Ga}$; Yamashita and Yanagi, 1994) of detrital zircons from pelitic gneisses on the Oki Islands, SW Japan. Moreover, it is almost identical with $\mathrm{Rb}-\mathrm{Sr}$ whole rock ages of metamorphic and granitic cobbles and boulders from the Kamiaso conglomerate (1.97 and $1.99 \mathrm{Ga}$; Shibata and Adachi, 1974) in Central Japan. These facts indicate that clastic sediments precursory of the Oki and Sangun metamorphic rocks were supplied from the common provenance composed of 1.9$2.0 \mathrm{Ga}$ granitic plutons and metamorphic rocks.

Korean peninsular, Northeast China and Eastern Siberia in the northeastern margin of the Asian continent are the most probable candidates for the provenance. In the paleogeographic reconstruction of the eastern margin of the Asian continent (Hiroi, 1981), Northéast China and Korean peninsular bordered on the Hida metamorphic belt before the Middle Miocene opening of the Sea of Japan. Many of Precambrian metamorphic and granitic rocks from these areas have radiometric ages of 1.7 to $2.2 \mathrm{Ga}$ (Yanagi and Yamaguchi, 1970; Hurley et al., 1973; Hamamoto et al., 1989; Sun et al., 1991).

Granitic plutons of $0.9 \mathrm{Ga}$ seem to be very few in Northeast China, Siberia and Korea (Yanagi and Yamaguchi, 1970; Lee, 1987). Yanagi and Yamaguchi (1970) reported a $1.0 \mathrm{Ga}$ granitic pluton from the central part of Korea, though the age was determined on biotite by $\mathrm{Rb}-\mathrm{Sr}$ dating method. In association with this, the detrital zircon age of $0.93 \pm 0.06 \mathrm{Ga}$ (Group 2) represents a time of plutonic activity in the provenance. The proportion of Group 2 zircon is about $10 \%$ by weight of the total zircon grains. Though we assumed the provenance in Northeast China, Siberia and Korea, possibility of transportation of clastic sediments from southern parts of China could not be ruled out, since 0.8 to $1.1 \mathrm{Ga}$ granitic plutons are rather abundant in the basement of the Sinian system in South China (Hu et al., 1989; Hu et al., 1991).

Figure 4 shows that rounded zircons (RP) are plotted closer to the upper intercept than short prismatic zircon (SP), and that purple zircons are plotted closer to the upper intercept than colorless zircon. It follows that the rounded purple zircons are plotted closest to the upper intercept and short
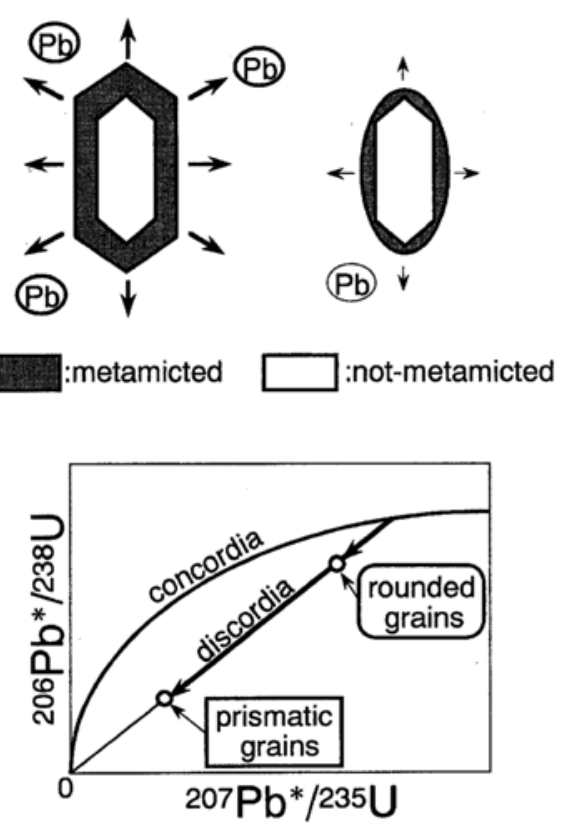

Fig. 6. A model of resetting of lead/uranium ratios. More abraded grains during transportation yield less discordant data from upper intercept, and less abraded grains yield more discordant. 
prismatic colorless zircon are plotted closest to the lower intercept. Therefore the problem is what makes these differences. In connection with this problem, it is worth noting that uranium content is higher in purple zircons than in colorless zircons (Table 3). Grain shapes, rounded or prismatic, are indifferent to uranium contents in zircons.

An often cited intuitive idea for the rounded purple zircons is that the zircons are very old and they are so abraded during repeated recycling as to perfectly loose their original crystal forms. This idea, however, is inconsistent with the fact that all the zircons of RP, DP, SP, RC and SC fractions define a common discordia as shown in Fig. 4. There is no positive evidence to suggest that the rounded purple zircons are much older than the short prismatic colorless zircons.

The most probable explanation is a different response of zircon crystals to natural abrasion during sediment transportation. As Krogh (1982) noted, the abrasion eliminates mechanically fragile parts due to the radiation damage. The same thing seems to have happened to the zircons during sediment transportation. Abrasion during the transportation has eliminated mechanically fragile parts which are easily susceptible to lead loss and the remaining rounded zircons have become tough against the lead loss. Because of this toughness of zircons, lead loss during the metamorphism seems to have been much suppressed. On the other hand, prismatic zircons have happened to escape from the abrasion during sediment transportation and hence still keep parts susceptible to lead loss. Much lead loss occurred with prismatic zircons during the metamorphism (Fig. 6). This explanation fits much to the observation. Then it follows that crystal forms such as rounded or prismatic are not related to recycling times of zircons but related to the response of zircons to the abrasion during the sediment transportation.

Acknowledgments-We thank Ms. R. Hamamoto and Mr. K. Yamashita who assisted us in isotopic analyses during the course of this study. Thanks are also due to two reviewers for reading the manuscript and making helpful suggestions. One of us (T. Miyamoto) was financially supported by Prof. T. Matsumoto scholarship fund.

\section{REFERENCES}

Baadsgaard, H. and Lerbekmo, J. F. (1980) A Rb/Sr age for the Cretaceous-Tertiary boundary ( $\mathrm{Z}$ coal), Hell Creak, Montana. Can. J. Earth Sci. 17, 671-673.

Cameron, A. E., Smith, D. H. and Walker, R. L. (1969) Mass spectrometry of nanogram-size samples of lead. Anal. Chem. 41, 525-526.

Hamamoto, R., Yanagi, T. and Nam, K. S. (1989) Rb$\mathrm{Sr}$ whole rock age of metamorphic rocks in the Sobaeksan Massif, Korea. Geol. Soc. Jpn. 96th Ann. Meet., Abstr. 110.

Hiroi, Y. (1981) Subdivision of the Hida metamorphic complex, central Japan, and its bearing on the geology of the far east in pre-Sea of Japan time. Tectonophysics 76, 317-333.

$\mathrm{Hu}$, S., Liu, H., Wang, S., Hu, W., Sang, H. and Qiu, J. (1989) On the age of Sinian lower boundary inferred from the new ${ }^{40} \mathrm{Ar} /{ }^{39} \mathrm{Ar}$ data. Sci. Geol. Sinica (1), 16-25 (in Chinese with English abstract).

$\mathrm{Hu}$, S., Liu, H. and Lao, Q. (1991) New geochronology of Sinian system. Sci. Geol. Sinica (4), 325-336 (in Chinese with English abstract).

Hurley, P. M., Fairbairm, H. W., Pinson, W. H., Jr. and Lee, J. H. (1973) Middle Precambrian and older apparent age values in basement gneisses of South Korea, and relations with Southwest Japan. Geol. Soc. Am. Bull. 84, 2299-2304.

Inoue, T. (1958) Structural geology of the metamorphic rocks region in Yame-Gun. Bull. Fukuoka Gakugei Univ., part 3 8, 39-46.

Krogh, T. E. (1982) Improved accuracy of U-Pb zircon ages by the creation of more concordant system using air abrasion technique. Geochim. Cosmochim. Acta 46, 6-13.

Lee, D. S. (1987) Geology of Korea. Kyohak-Sa, Seoul, $514 \mathrm{pp}$.

Ludwig, K. R. (1980) Calculation of uncertainties of $\mathrm{U}-\mathrm{Pb}$ isotope data. Earth Planet. Sci. Lett. 46, 212220.

Matsumoto, T. (1958) Geology of the metamorphic areas in the Chikushi Mountains, North Kyushu. Jubilee Publication in Commemoration of the Sixtieth Birthday of Prof. Jun Suzuki, Hokkaido Univ., 141161.

Mattinson, J. M. (1972) Preparation of hydrofluoric, hydrochloric, and nitric acids at ultralow lead levels. Anal. Chem. 44, 1715-1716.

Miyashiro, A. (1961) Evolution of metamorphic belts. Jour. Petrol. 2, 277-311.

Nishimura, Y. (1989) Sangun metamorphic rocks. Terrane Problem (Ichikawa, K. et al., eds.), 63-78, IGCP Proj. 224: Pre-Cretaceous Terranes of Japan, Osaka City Univ.

Shibata, K. and Adachi, M. (1974) Rb-Sr whole rock 
ages of Precambrian metamorphic rocks in the Kamiaso conglomerate from central Japan. Earth Planet. Sci. Lett. 21, 277-287.

Stacey, J. S. and Kramers, J. D. (1975) Approximation of terrestrial lead isotope evolution by a two stage model. Earth Planet. Sci. Lett. 26, 207-221.

Steiger, R. H. and Jäger, E. (1977) Subcommission on geochronology: convention on the use of decay constants in geo- and cosmochronology. Earth Planet. Sci. Lett. 36, 359-362.

Sun, D., Li, H., Lin, Y., Zhou, H., Zhao, F. and Tang, M. (1991) Precambrian geochronology, chronotectonic framework and model of chronocrustal structure of the Zhongyiao Mountains. Acta Geol. Sinica 65, 216-231 (in Chinese with English abstract).

Yamashita, K. and Yanagi, T. (1994) U-Pb and Rb-Sr dating of the Oki metamorphic rocks, the Oki Island, Southwest Japan. Geochem. J. 28, 333-339.

Yanagi, T. (1969) Petrological study of the Chikugo metamorphic rocks. Sci. Rep. Fac. Sci. Kyushu Univ., Geol. 9, 89-98 (in Japanese with English abstract).

Yanagi, T. (1990) A new method for accurate determination of isotopic composition and concentration of strontium in a spike solution used for geochronological works. Mass Spectrosc. 38, 193-198.

Yanagi, T. and Yamaguchi, M. (1970) Ages of some Precambrian metamorphic rocks in North China. Mem. Fac. Sci., Kyushu Univ., Ser. D, Geol. 20, 177 189.

Yanagi, T., Baadsgaard, H., Stelck, C. R. and McDougall, I. (1988) Radiogenic dating of a tuff bed in the middle Albein Hulcross Formation at Hudson's Hope, British Columbia. Can. J. Earth Sci. 25, 1123 1127.

York, D. (1966) Least-squares fitting of a straight line. Can. J. Phys. 44, 1079-1086.

York, D. (1969) Least squares fitting of a straight line with correlated errors. Earth Planet. Sci. Lett. 5, 320 324. 